\title{
TORSADES DE POINTES IN ELDERLY PATIENT WITH PAROXYSMAL ATRIAL FIBRILLATION TREATED BY SHORT-TERM PARENTERAL AMIODARONE THERAPY
}

\author{
Nenad Lakušić1 Valentina Slivnjak $^{2}$, Nedeljko Ciglenečki ${ }^{3+}$ and Duško Cerovec ${ }^{1}$ \\ ${ }^{1}$ Department of Cardiology, Krapinske Toplice Hospital for Medical Rehabilitation, Faculty of Medicine and \\ Faculty of Dental Medicine and Health, Josip Juraj Strossmayer University of Osijek, Krapinske Toplice, Croatia; \\ ${ }^{2}$ Department of Internal Medicine, Krapinske Toplice Hospital for Medical Rehabilitation, \\ Krapinske Toplice, Croatia; \\ ${ }^{3}$ Intensive Care Unit, Krapinske Toplice Hospital for Medical Rehabilitation, Krapinske Toplice, Croatia \\ SUMMARY - One of the drugs that are widely used in the treatment of atrial fibrillation is \\ amiodarone. Despite considerable prolongation of the corrected QT interval and a substantial degree \\ of bradycardia, amiodarone exhibits a remarkably low frequency of pro-arrhythmic events and $<1.0 \%$ \\ incidence of torsades de pointes, mostly after long-term usage. We present a case of an 80-year-old \\ female with paroxysmal atrial fibrillation accompanied by acute heart failure treated by short-term \\ parenteral amiodarone therapy and development of torsades de pointes.
}

Key words: Torsades de pointes; Amiodarone; Atrial fibrillation; Bradycardia; Case reports

\section{Introduction}

Atrial fibrillation is one of the most common arrhythmias in daily clinical practice, associated with a significant risk of stroke, congestive heart failure, and higher mortality rate ${ }^{1}$. One of the drugs that are widely used in treating atrial fibrillation is amiodarone. Amiodarone is a unique antiarrhythmic agent of a 'wide-spectrum', primarily of class III activity (prolongs phase 3 of the cardiac action potential, the repolarization phase where there is normally decreased calcium permeability and increased potassium permeability) ${ }^{2}$. Besides efficacy in the treatment of patients with atrial fibrillation and ventricular arrhythmias, treatment with amiodarone is associated with numerous possible side effects. Despite considerable prolon-

Correspondence to: Prof. Nenad Lakušic, $M D, P h D$, Department of Cardiology, Krapinske Toplice Hospital for Medical Rehabilitation, Gajeva 2, HR-49217 Krapinske Toplice, Croatia E-mail: nenad.lakusic@sbkt.hr

Received November 15, 2016, accepted September 11, 2017 gation of the corrected QT interval (QTc) and a substantial degree of bradycardia, amiodarone exhibits a remarkably low frequency of pro-arrhythmic events and $<1.0 \%$ incidence of torsades de pointes, mostly after long-term usage ${ }^{3,4}$. Torsades de pointes is a lifethreatening arrhythmia associated with prolongation of the QTc interval on electrocardiogram (ECG). The treatment of hemodynamically stable torsades de pointes involves discontinuation of the offending drug(s), correction of electrolyte abnormalities and administration of intravenous magnesium sulfate 5 .

We present a case of an 80-year-old female with paroxysmal atrial fibrillation accompanied by acute heart failure treated by short-term parenteral amiodarone therapy and development of torsades de pointes.

\section{Case Report}

An 80-year-old female was admitted to the Intensive Care Unit (ICU) of our hospital due to paroxysmal atrial fibrillation with rapid ventricular response 


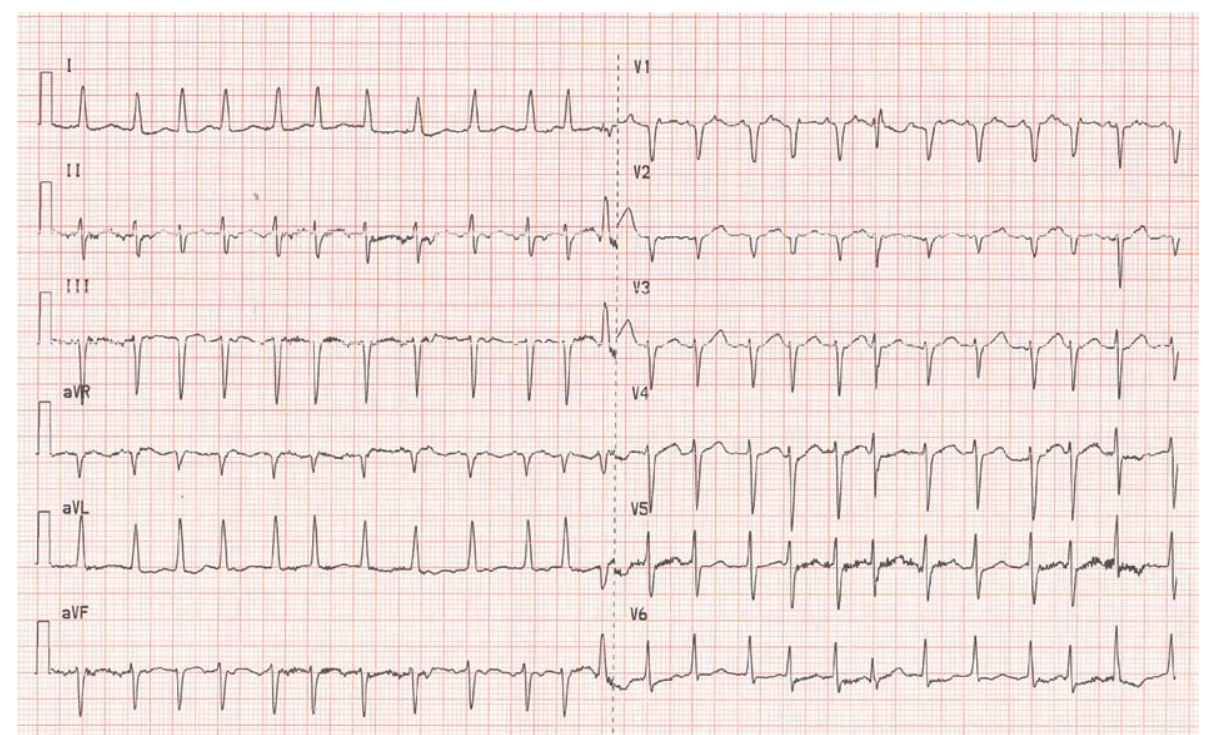

Fig. 1. Paroxysmal atrial fibrillation at admission.

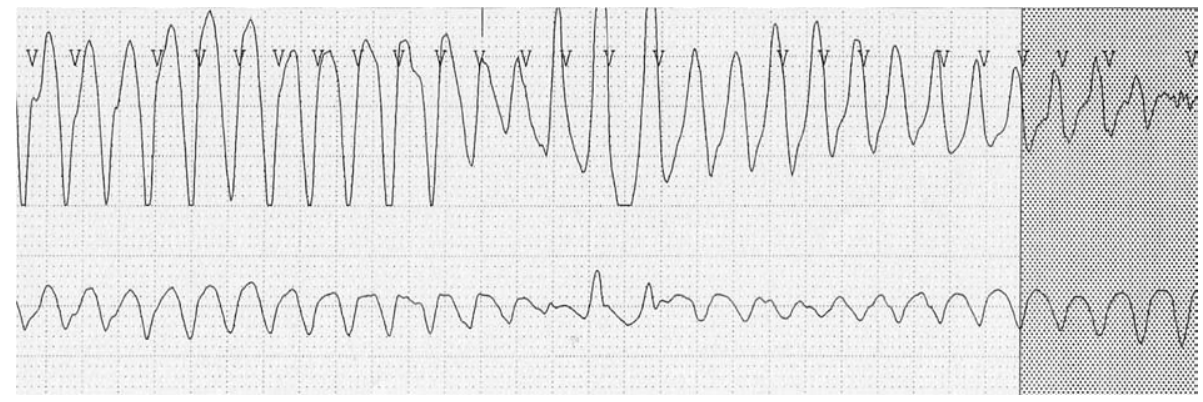

Fig. 2. Torsades de pointes during short-term amiodarone treatment.

(Fig. 1) accompanied by acute heart failure. Arterial hypertension had been present for one year but the patient failed to take the recommended antihypertension therapy on regular basis (lacidipine $4 \mathrm{mg}$ ). In the last two weeks prior to admission to the hospital, the patient started noticing progressive effort intolerance accompanied by dyspnea. Upon her admission to the hospital, the signs of acute heart failure were found clinically and radiologically, along with newly diagnosed atrial fibrillation with ventricular tachyarrhythmia up to $200 / \mathrm{min}$.

Laboratory results showed mild macrocytic anemia (hemoglobin (Hb) $115 \mathrm{~g} / \mathrm{L}$; mean corpuscular volume (MCV) 108), chronic renal insufficiency (urea 11.1 $\mathrm{mmol} / \mathrm{L}$; creatinine $171 \mu \mathrm{mol} / \mathrm{L}$; creatinine clearance (Cockcroft-Gault equation) $30.2 \mathrm{~mL} / \mathrm{min}$ ) and mild hypokalemia $(3.7 \mathrm{mmol} / \mathrm{L})$. ECG did not show significant ST-T changes (high-sensitivity troponin I (hs-troponin I) $56.1 \mathrm{ng} / \mathrm{L}$. Treatment with enoxaparin $60 \mathrm{mg}$ s.c., furosemide $40 \mathrm{mg}$ i.v., potassium substitution and amiodarone infusion was initiated at Emergency Room (ER), then the patient was transferred to the ICU where amiodarone infusion was continued.

Shortly after therapy had been initiated, ventricular frequency slowed down significantly to $<100 / \mathrm{min}$, with regression of the patient's subjective symptoms. Approximately six hours after initiating the administration of amiodarone, the patient experienced torsades de pointes paroxysms lasting for up to 10 seconds (Fig. 2). Both paroxysms were noted at night while the patient was asleep. The paroxysms ceased spontaneously, hence there was no need for resuscitation or electrical cardioversion. After that, the i.v. amiodarone infusion was terminated, the magnesium and potassium concentrations were measured and proved to be 


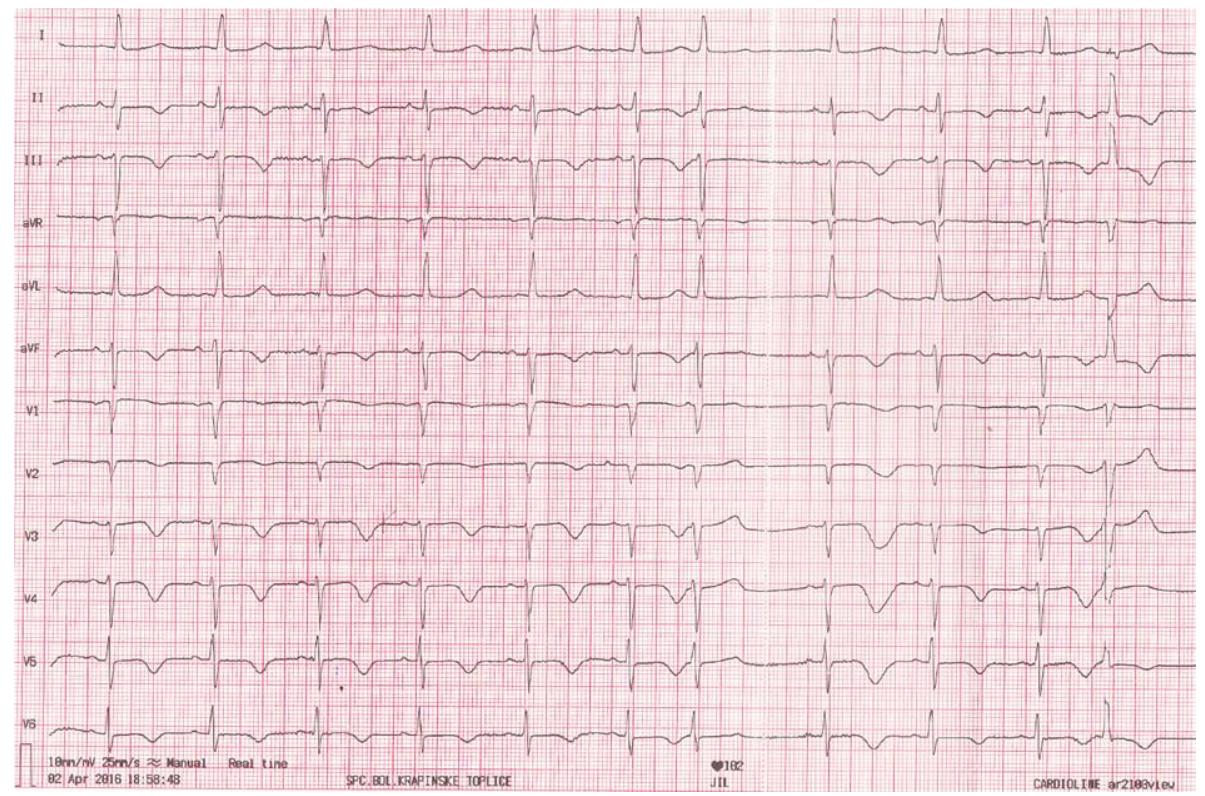

Fig. 3. Significant QTc prolongation (569 ms).

lowered (Mg $0.49 \mathrm{mmol} / \mathrm{L}, \mathrm{K} 3.5 \mathrm{mmol} / \mathrm{L})$, and significant QTc prolongation up to $569 \mathrm{~ms}$ was found on the new ECG recording (Fig. 3) with wide, biphasic to negative $\mathrm{T}$ waves in inferior and V3-V6 leads and unstable sinus rhythm with supraventricular and ventricular ectopic beats. Shortly after that, the patient experienced another torsades de pointes paroxysm with repeated spontaneous conversion into sinus rhythm without losing her consciousness. Magnesium sulfate was immediately introduced into therapy at a dosage of $9 \mathrm{mmol}(2.25 \mathrm{~g})$ i.v. bolus, which was followed by continuous magnesium infusion alongside potassium substitution and bisoprolol at a dosage of $1.25 \mathrm{mg}$. Clinically, the patient no longer experienced significant dyspnea or chest pain and laboratory results showed no dynamics that would indicate acute coronary syndrome (follow up hs-troponin I 50.3, 36.6 $\mathrm{ng} / \mathrm{L})$. The ECHO-cardiogram showed mild to moderate mitral regurgitation, left atrium of borderline diameter $(4.0 \mathrm{~cm})$, angio $2+$ tricuspid regurgitation with estimated pressure in the right ventricle up to $40 \mathrm{~mm}$ $\mathrm{Hg}$, non-dilated (LVIDd $4.5 \mathrm{~cm}$ ) and non-hypertrophic left ventricle with left ventricular ejection fraction (EFLV) 45\%-50\%, without clear segmental kinetic abnormalities (2D). After amiodarone therapy had been discontinued and electrolyte imbalance corrected $(\mathrm{Mg} 1.29,0.97 \mathrm{mmol} / \mathrm{L})$, there were no torsades de pointes attacks. Within the next few days, the patient's condition gradually stabilized, there were no signs of acute heart failure, and sinus rhythm stabilized with rare short-term paroxysms of atrial fibrillation. Medical therapy was optimized, warfarin was introduced. The QTc interval gradually decreased to $447 \mathrm{~ms}$ and T wave positivity (Fig. 4) was followed by serial ECG recording two weeks after admission to the hospital and amiodarone introduction. The patient was discharged in a stable condition with the following therapy: warfarin $1.5 \mathrm{mg}$, ramipril/amlodipine $5 / 5 \mathrm{mg}$, furosemide $40 \mathrm{mg}$, eplerenone $50 \mathrm{mg}$ and bisoprolol $1.25 \mathrm{mg}$.

\section{Discussion}

Although it is well known that different drugs can lead to significant prolongation of the QTc interval and subsequent torsades de pointes phenomena, the case presented is relatively rare since it occurred after a very short amiodarone administration, i.e. already 6 hours after the medication had been administered. There are literature data on QTc prolongation and the incidence of torsades de pointes after long-term ${ }^{6,7}$, as well as short-term drug administration, 4-5 days from treatment initiation ${ }^{3}$.

The known risk factors for torsades de pointes include QTc interval $>500 \mathrm{~ms}$, QTc interval increase by $\geq 60 \mathrm{~ms}$ from the pretreatment value, advanced age, fe- 

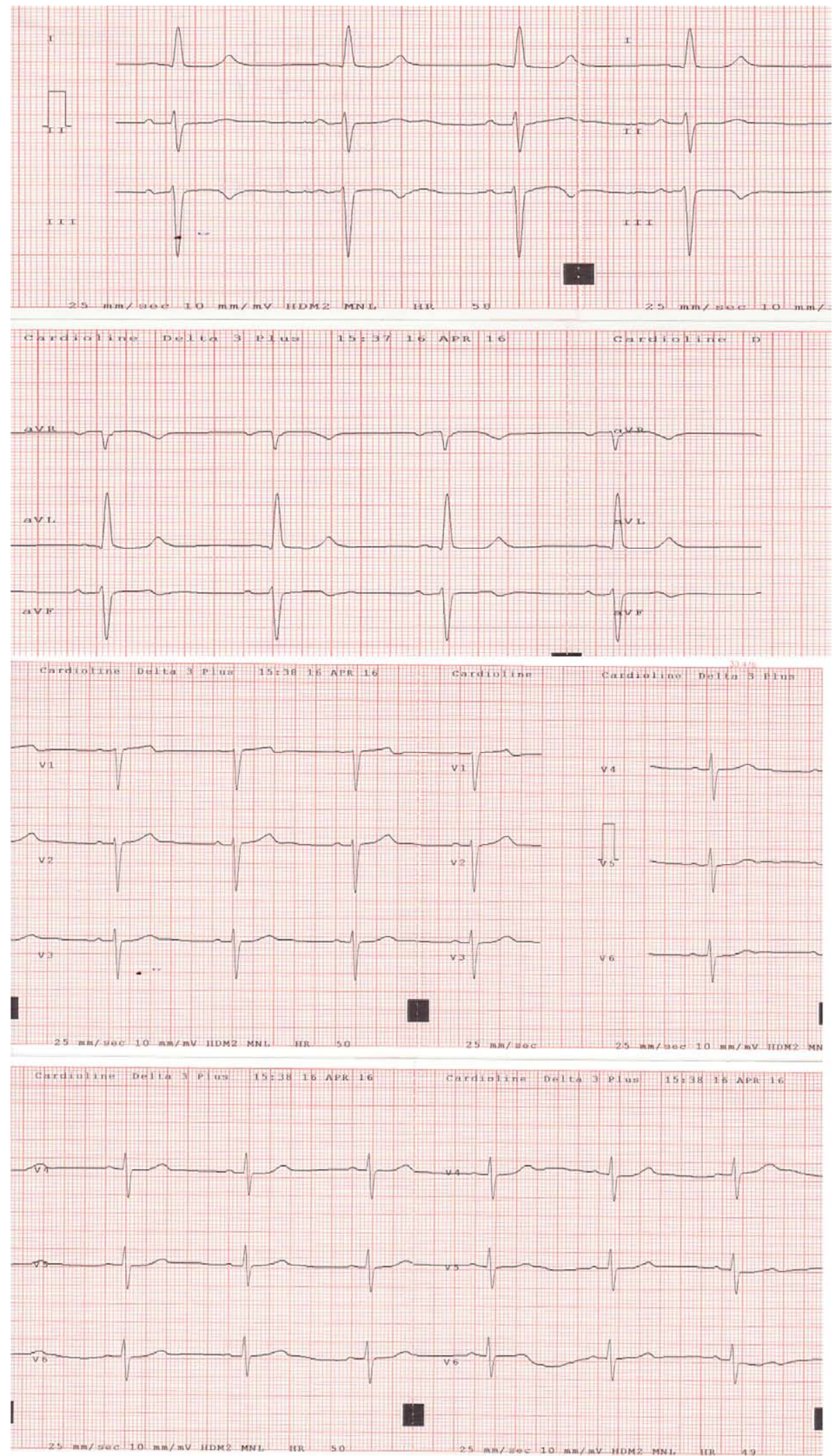

Fig. 4. ECG at discharge (QTc 447 ms). 
male sex, acute myocardial infarction, heart failure with reduced ejection fraction, hypokalemia, hypomagnesemia, hypocalcemia, bradycardia, treatment with diuretics and elevated plasma concentrations of QTc interval-prolonging drugs due to drug interactions, inappropriate dose adjustment of kidney eliminated drugs in patients with kidney disease and rapid intravenous administration ${ }^{8,9}$.

Besides amiodarone therapy, there were several predisposing factors for the occurrence of torsades de pointes in our patient, including age, gender, moderate renal failure, hypomagnesemia and hypokalemia in the acute phase and QTc interval at the upper limit of the normal value.

Drug-induced excessive QT prolongation most commonly occurs in patients with subclinical mutations in one of the genes responsible for the congenital long QT syndrome ${ }^{10}$. These patients are susceptible to developing torsades de pointes if administered a drug that blocks potassium channels. The percentage of carriers of genetic defects in the acquired long QT syndromes is still unknown ${ }^{3}$.

Considering the occurrence of torsades de pointes after short-term amiodarone administration with significant QTc prolongation and the fact that QTc interval was at the upper limit of the normal value at discharge from the hospital, our patient probably belongs to the susceptible group of patients who have silent mutations in the function of potassium ion channels.

Using amiodarone as first-line therapy in the acute phase of disease was another important problem in the treatment of the patient presented. Taking into consideration current guidelines for the treatment of $\mathrm{pa}^{-}$ tients with atrial fibrillation ${ }^{1}$, amiodarone should not have been the first-line treatment at admission in the case described because there were no records of arrhythmia duration, size of the left atrium or possible thrombus presence in the left atrial auricle. In accordance with the guidelines, the first-line treatment in this patient should have been administration of digitalis for rate control. Considering a relatively large number of similar patients admitted to ERs due to acute heart failure accompanied by paroxysmal atrial fibrillation and/or ventricular arrhythmias and wide amiodarone administration (often without a clear stronghold in the guidelines), the aim of this presentation is to warn clinicians of the possible rare side ef- fects of such a treatment even after short-term amiodarone administration, the necessity of immediate discontinuation of the drug from therapy and specific treatment in case of the occurrence of torsades de pointes, which involves administration of magnesium sulfate, correction of hypokalemia, lidocaine administration $^{11}$, temporary pacing, and in the most severe cases, electrical cardioversion and resuscitation.

In conclusion, we would like to emphasize the importance of careful patient monitoring during amiodarone therapy, even at short-term usage, and using the drug in accordance with current guidelines ${ }^{1}$.

\section{References}

1. Kirchhof P, Benussi S, Kotecha D, Ahlsson A, Atar D, Casadei B, et al. 2016 ESC Guidelines for the management of atrial fibrillation developed in collaboration with EACTS. Eur Heart J. 2016;37:2893-962. doi: 10.1093/eurheartj/ehw210

2. Opie LH, Gersh BJ. Drugs for the heart. $7^{\text {th }}$ edn. Philadephia, USA: Saunders Elsevier, 2009; p. 252-9.

3. Lim HE, Pak HN, Ahn JC, Song WH, Kim YH. Torsades de pointes induced by short-term oral amiodarone therapy. Europace. 2006;8:1051-3. doi: 10.1093/europace/eul118

4. Hohnloser SH, Klingenheben T, Singh BN. Amiodarone-associated proarrhythmic effects. A review with special reference to torsades de pointes tachycardia. Ann Intern Med. 1994;121: 529-35. doi: 10.7326/0003-4819-121-7-199410010-00009

5. Tisdale JE. Drug-induced QT interval prolongation and torsades de pointes: role of the pharmacist in risk assessment, prevention and management. Can Pharm J (Ott). 2016;149: 139-52. doi: $10.1177 / 1715163516641136$

6. Franchi C, Ardoino I, Rossio R, Nobili A, Biganzoli EM, Marengoni A, et al.; REPOSI Investigators. Prevalence and risk factors associated with use of QT-prolonging drugs in hospitalized older people. Drugs Aging. 2016;33:53-61. doi: 10.1007/s40266-015-0337-y.

7. Keller GA, Alvarez PA, Ponte ML, Belloso WH, Bagnes C, Sparanochia C, et al. Drug-induced QTc interval prolongation: a multicenter study to detect drugs and clinical factors involved in every day practice. Curr Drug Saf. 2016;11:86-98. doi: 10.2174/1574886311207040262

8. Trinkley KE, Page RL $2^{\text {nd }}$, Lien $H$, Yamanouye K, Tisdale JE. $\mathrm{QT}$ interval prolongation and the risk of torsades de pointes: essentials for clinicians. Curr Med Res Opin. 2013;29:1719-26. doi: 10.1185/03007995.2013.840568.

9. Drew BJ, Ackerman MJ, Funk M, Gibler WB, Kligfield P, Menon $\mathrm{V}$, et al.; on behalf of the American Heart Association Acute Cardiac Care Committee of the Council on Clinical Cardiology, the Council on Cardiovascular Nursing and the American College of Cardiology Foundation. Prevention of torsades de pointes in hospital settings: a scientific statement 
from the American Heart Association and the American College of Cardiology Foundation. Circulation. 2010;121:104760. doi: 10.1161/CIRCULATIONAHA.109.192704

10. Priori SG, Napolitano C, Schwartz PJ. Low penetrance in the long QT syndrome: clinical impact. Circulation. 1999;99: 529-33. doi: 10.1161/01.cir.99.4.529
11. Yelgeç NS, Alper AT, Tekkeşin AI, Türkkan C, Gürkan K. Recurrent torsades de pointes due to amiodarone toxicity treated successfully with lidocaine. West Indian Med J. 2015;65:421-2. doi: $10.7727 /$ wimj.2014.211

Sažetak

\section{TORSADES DE POINTES U BOLESNICE STARIJE ŽIVOTNE DOBI S PAROKSIZMALNOM ATRIJSKOM FIBRILACIJOM LIJEČENE KRATKOROČNOM PARENTERALNOM PRIMJENOM AMIODARONA}

\section{N. Lakušic, V. Slivnjak, N. Ciglenečkit i D. Cerovec}

Jedan od lijekova koji se široko rabi u liječenju atrijske fibrilacije je amiodaron. Unatoč značajnom produljenju korigiranog QT intervala i usporavanju srčanog rada, amiodaron pokazuje iznimno nisku učestalost pro-aritmičkih događaja i $<1,0 \%$ učestalosti torsades de pointes, uglavnom nakon dugotrajne uporabe. U radu je prikazan slučaj 80-godišnje žene s paroksizmalnom atrijskom fibrilacijom praćenom akutnim zatajenjem srca liječenom kratkotrajnom parenteralnom primjenom amiodarona i razvojem torsades de pointes.

Ključne riječi: Torsades de pointes; Amiodaron; Atrijska fibrilacija; Bradikardija; Prikazi slučaja 